\title{
Mucosal peptic activity during Helicobacter pylori infection in pediatric patients
}

\author{
J Yahav, G Oderda, A Diver-Haber, N Keller, A Jonas
}

\begin{abstract}
Intramucosal peptic activity may participate in the genesis of acute and chronic superficial gastritis. The proteolytic activity of homogenates of gastric mucosa (antrum and body) and duodenum were measured at $\mathrm{pH} 2.0$ (total peptic activity) after exposure to $\mathrm{pH} 8.0$ (pepsinogen) and the activated pepsinogen (pepsin) was calculated in pediatric patients investigated for the presence of Helicobacter pylori (H pylori), 122 antral, 77 stomach body, and 74 duodenal biopsies were examined in 43 $H$ pylori positive patients, 51 controls, and 28 $\boldsymbol{H}$ pylori negative gastritis patients. Activated pepsinogen was significantly reduced in the stomach of $\boldsymbol{H}$ pylori positive patients only. Pepsinogen values were similar in all the anatomical areas tested in all patients. In 13 $H$ pylori positive patients reinvestigated three months after antibiotic therapy, antral mucosal activated pepsinogen activity increased significantly (mean pretreatment $1.56(1.0) \mathrm{U} / \mathrm{mg}$ protein versus mean posttreatment $2.72(1 \cdot 7) \mathrm{U} / \mathrm{mg}$ protein) and reached values comparable with controls. The decreased activated pepsinogen activity in association with normal pepsinogen content observed in the antrum of $H$ pylori positive gastritis patients indicate local pepsin inactivation or alternately enhanced removal into the gastric lumen or backflow into the circulation. Gut 1992; 33: 1162-1165
\end{abstract}

Accumulating evidence supports the concept that Helicobacter pylori infection plays a causative role in gastric inflammation in children.$^{1-3}$ On the grounds of epidemiologic studies, based on specific serum antibodies, $H$ pylori was considered to be uncommon in childhood and to increase progressively with age. ${ }^{+}$The reduced colonisation rate of children compared with adults disappears when patients with primary antral gastritis are considered specifically. Although studies have shown a striking correlation between the presence of $H$ pylori and classic inflammation of the antral mucosa, ${ }^{5-7}$ the exact mechanism of tissue injury remains obscure.

In this study the peptic activity was determined in gastric mucosa obtained from children with $H$ pylori infection compared with noninfected patients with evidence of gastritis and with those with normal gastric histology.

\section{Methods}

PATIENTS

During the period June 1989 to June 1990 children undergoing endoscopy for various reasons in both medical centres (Tel Hashomer and Torino) were prospectively tested for the presence of $H$ pylori infection. Endoscopy was carried out after sedation, using an Olympus GIF-10 fibreoptic endoscope. Biopsy specimens were obtained from the gastric body, antrum, and duodenum for the following procedures: routine histology, $H$ pylori culture (antral only), urease test (antral only), and peptic activity determination. Not all procedures were done in every patient. Biopsies for histological preparation were fixed in Bouin's solution, sectioned, stained with haematoxylin and eosin, Giemsa and Gram stain and examined for the presence of $H$ pylori and signs of inflammation. Mucosal inflammation was identified by the presence of increased numbers of acute or chronic inflammatory cells. The classification of gastritis was made without knowing the results of the Giemsa staining, urease test or pepsinogen determination. Antral biopsies cultured for $H$ pylori were inoculated onto blood agar and Skirrow's medium and incubated at $37^{\circ} \mathrm{C}$ in an anaerobic environment for seven days. Urease test used the Christensen formulation without agar. Change of medium colour was tested after 24 hours. The criteria for $H$ pylori infection were based on the presence of histopathological evidence of gastritis and of typical bacilli on staining, a positive urease test and or culture.

Biopsy specimens for peptic activity determination were immediately homogenised in $1 \mathrm{ml}$ $\mathrm{H}_{2} \mathrm{O}$ using Ultra Turax T25 homogeniser (Ianke and Kunkel). Homogenates were stored at $-20^{\circ} \mathrm{C}$ in $10 \%$ glycerol solution. The peptic activity of mucosal homogenates was determined in an assay at $\mathrm{pH} 2.0$ by the method of Anson and Mirsky ${ }^{8}$ and expressed as specific activity (IU/mg protein); aliquots of mucosal homogenates assayed by this method were considered as representing total peptic activity. Separate aliquots of the same mucosal homogenates were assayed for peptic activity after being exposed to pH 8.0 by alkalinisation using $1 \mathrm{~N} \mathrm{NaOH}$. The peptic activity obtained in these aliquots was considered to represent pepsinogen concen-

TABLE I Specific activity of total peptic activity, pepsinogen and activated pepsinogen in antral biopsies

\begin{tabular}{|c|c|c|c|}
\hline & $\begin{array}{l}\text { Total peptic } \\
\text { activity } \\
\text { IU/mg protein }\end{array}$ & $\begin{array}{l}\text { Pepsinogen } \\
\text { IU/mg protein }\end{array}$ & $\begin{array}{l}\text { Activated } \\
\text { pepsinogen } \\
\text { (pepsin) } \\
\text { IU/mg protein }\end{array}$ \\
\hline $\begin{array}{l}\text { Group I (43) } \\
\text { Group II (28) } \\
\text { Controls }(51) \\
\star^{\star}=<0 \cdot 001 \\
+\mathrm{p}=<0 \cdot 01\end{array}$ & $\begin{array}{l}1.81(1.13)^{\star} \\
2.39(0.83) \dagger \\
3.03(1.25)\end{array}$ & $\begin{array}{l}0.52(0.56) \\
0.36(0.32) \\
0.49(0.45)\end{array}$ & $\begin{array}{l}1.34(1.03)^{\star} \\
2.04(0.87) \dagger \\
2.54(1.29)\end{array}$ \\
\hline
\end{tabular}

${ }^{\star} \mathrm{p}$ Values of group I $v$ controls; tp value of group I $v$ group II Obtained by Student's $t$ test. Results are given as mean (SD). 
tration. Activated pepsinogen (pepsin) was calculated by subtracting pepsinogen from total peptic activity values. Protein was determined according to Lowry. ${ }^{9}$

Patients were treated with antibiotics (three weeks of amoxycillin. $50 \mathrm{mg} / \mathrm{kg} / 24$ hours tid followed by two weeks of metronidazole $20 \mathrm{mg} /$ $\mathrm{kg} / 24$ hours tid). At least three months post treatment endoscopy was performed and biopsies were obtained for the same procedures as above.

\section{STATISTICAL ANALYSIS}

All results are expressed as mean (SD). The difference between means of two groups was evaluated by unpaired Student's $t$ test with $\mathrm{p}<0.05$ considered as significant.

\section{Results}

One hundred and twenty two patients were included in this study. The mean age of patients was $11.5(3.8)$ year range (two to 18 years). There were 72 males and 50 females $(M: F$ ratio $1 \cdot 4: 1 \cdot 0)$.

Patients were divided into three groups according to the presence of histological gastritis and evidence of $H$ pylori infection by at least one criterion.

GROUP I

$H$ pylori positive gastritis was found in 43 patients. Their mean age was $12 \cdot 5$ years and $M: F$ ratio $=1 \cdot 6: 1 \cdot 0 \mathrm{H}$ pylori infection was diagnosed by histology in $40 / 41$, by a positive urease test in $23 / 25$ and by culture in $19 / 27$.

GROUP II

$H$ pylori negative gastritis was present in 28 patients. The histology indicated chronic active antral gastritis in all patients. Mean age of this group was $12 \cdot 6$ years and the $M: F$ ratio $1 \cdot 5: 1 \cdot 0$. This group included 12 patients who have previously been treated with oral antibiotics for various reasons, six patients with chronic inflammatory bowel disease, six patients with associated inflammatory disease of the oesophagous and/or stomach and/or duodenum.

GROUP III

Controls, had no evidence of gastritis or $H$ pylori infection. This group included 51 patients, with a mean age of 10 years significantly lower than the previous two groups $(\mathrm{p}<0.004)$, the $M: F$ ratio was $1 \cdot 2: 1 \cdot 0$.

The peptic activity of antral biopsies was determined in all 122 patients. Results are shown in Table $\mathbf{I}$.

Significantly decreased antral total peptic activity was found in patients with $H$ pylori positive gastritis compared with control, and $H$ pylori negative gastritis. This was mainly the result of diminished activated pepsinogen (pepsin) activity, while pepsinogen concentrations were normal.

Activated pepsinogen was slightly decreased in gastritis $H$ pylori negative patients compared with controls.

The peptic activity of biopsies obtained from the stomach body region was determined in 77 patients (Table II). Decreased concentrations of activated pepsinogen were found in $H$ pylori positive patients only.

Duodenal biopsies were tested in 76 patients. No significant difference among the three groups was observed (Table III).

\section{EFFECT OF TREATMENT ON MUCOSAL PEPTIC} ACTIVITY

Thirteen patients (seven females and six males) positive for $H$ pylori were reinvestigated three months after the completion of antibiotic therapy. No evidence of $H$ pylori infection or mucosal inflammation were present at the time of reinvestigation. We found a significant difference in the antral mucosal peptic activity before and after treatment. Total peptic activity and activated pepsinogen of the antral mucosa increased after eradication of $H$ pylori infection but remained lower than controls (Table IV). Duodenal and stomach body biopsies showed no significant changes compared with pretreatment biopsies (Date not shown). Individual values of activated pepsinogen showed significant increased activity in 10 of the 13 patients tested (Figure).

\section{Discussion}

This study shows a close association between $H$ pylori induced gastritis and diminished peptic activity of the gastric mucosa, both in the active stage of the disease as well as after eradication of infection when values returned to normal.

TABLE II Specific activity of total peptic activity, pepsinogen and activated pepsinogen in stomach body biopsies

\begin{tabular}{llll}
\hline & $\begin{array}{l}\text { Total peptic } \\
\text { activity } \\
\text { IU/mg protein }\end{array}$ & $\begin{array}{l}\text { Pepsinogen } \\
\text { IU/mg protein }\end{array}$ & $\begin{array}{l}\text { Activated } \\
\text { pepsinogen } \\
\text { IU/mg protein }\end{array}$ \\
\hline Group I (30) & $3.89(1 \cdot 63)$ & $0 \cdot 29(0 \cdot 32)$ & $3 \cdot 60(1 \cdot 71)^{\star}$ \\
Group II (11) & $5 \cdot 13(2 \cdot 34)$ & $0 \cdot 13(0 \cdot 14)$ & $4.99(2 \cdot 36)$ \\
Controls (36) & $4 \cdot 47(1.56)$ & $0 \cdot 19(0 \cdot 19)$ & $4 \cdot 27(1 \cdot 62)$ \\
${ }^{\star} \mathrm{p}=<0.05$ & & & \\
\hline
\end{tabular}

${ }^{\star} \mathrm{p}$ Values of group I $v$ controls, obtained by Student's $t$ test. Results are expressed as mean (SD)

TABLE III Specific activity of pepsin pepsinogen and activated pepsinogen in duodenal biopsies

\begin{tabular}{llll}
\hline & $\begin{array}{l}\text { Total peptic } \\
\text { activity } \\
\text { IU/mg protein }\end{array}$ & $\begin{array}{l}\text { Pepsinogen } \\
\text { IU/mg protein }\end{array}$ & $\begin{array}{l}\text { Activated } \\
\text { pepsinogen } \\
\text { IU/mg protein }\end{array}$ \\
\hline Group I (30) & $0.95(1.05)$ & $0.29(0.13)$ & $0.70(1.02)$ \\
Group II (10) & $0.81(0.62)$ & $0.11(0.13)$ & $0.71(0.59)$ \\
Controls (36) & $0.82(0.75)$ & $0.31(0.35)$ & $0.61(0.64)$ \\
\hline
\end{tabular}

TABLE IV Antral biopsies specific activity pre v post treatment in 13 patients

\begin{tabular}{lclc}
\hline & $\begin{array}{l}\text { Total peptic } \\
\text { activity } \\
\text { IU/mg protein }\end{array}$ & $\begin{array}{l}\text { Pepsinogen } \\
\text { IU/mg protein }\end{array}$ & $\begin{array}{l}\text { Activated } \\
\text { pepsinogen } \\
\text { IUImg protein }\end{array}$ \\
\hline Pretreatment & $1 \cdot 76(1 \cdot 0)^{\star}$ & $0 \cdot 31(0 \cdot 47)$ & $1.56(1 \cdot 07)^{\star}$ \\
Post treatment & $3.03(1 \cdot 12)$ & $0 \cdot 21(0 \cdot 28)$ & $2 \cdot 72(1 \cdot 20)$ \\
p & $<0.006$ & NS & $<0.01$ \\
\hline
\end{tabular}

p Values of pre $v$ post treatment patients, obtained by Student's $t$ test. 
Individual values of activated pepsinogen in antral mucosae before and after treatment.

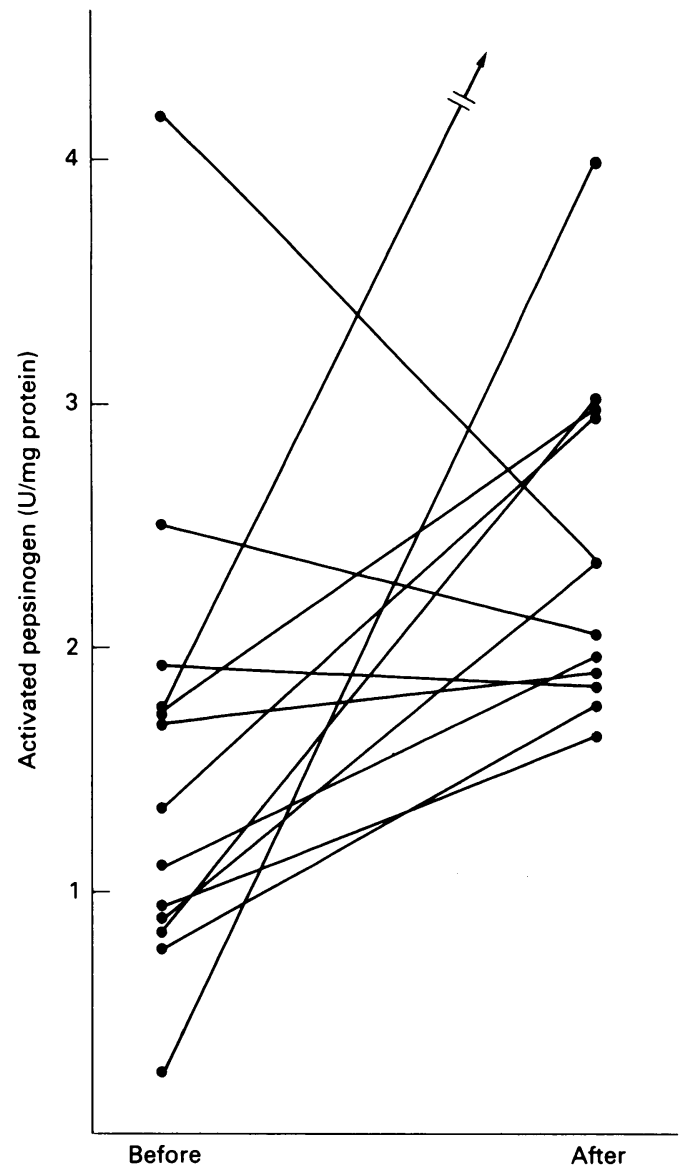

Decreased peptic activity was present not only in the antral mucosa but also in the less affected mucosa of the gastric body. $H$ pylori is classically associated with inflammation of the antrum but not exclusively so. Significant degrees of colonisation were found in gastritis located in the body of the stomach when this was specifically sought after, especially in the early stage of the disease. $^{31011}$ The dynamics and importance of $H$ pylori reduced altered mucosal peptic activity is far from being clarified. The only report investigating and supporting our finding of reduced gastric peptic activity in $H$ pylori infection comes from an unusual case report which followed the natural history of $H$ pylori infection in a volunteer. ${ }^{12}$

The peptic activity of $H$ pylori infected mucosa was significantly reduced in comparison with normal mucosa as well as that of patients with gastritis not associated with $H$ pylori infection. We were unable to determine the aetiology of the gastritis in every patient of this latter group; histology failed to detect features of secondary gastritis, ${ }^{5}$ but additional sites of inflammation of the gastrointestinal mucosa were found in most of these patients. Twelve of these children received previous antibiotic therapy for various reasons, with possible inadvertent effects on the diagnosis of $H$ pylori. The results of other studies in children confirm the existence of $H$ pylori negative antral gastritis in $30 \%$ of children, especially of a younger age group. ${ }^{35}$

The decreased peptic activity observed in our patients with $H$ pylori infection was the result of decreased activated pepsinogen (pepsin) activity, while pepsinogen, determined after alkalinisation of mucosal homogenates, remained comparable with control.

The gastric peptic activity derives from a diversity of intracellular enzymes whose activity depends on the rate of secretion and the ambient $\mathrm{pH} .{ }^{13}$ Peptic activity is $\mathrm{pH}$ dependent and pepsin is irreversibly denaturated at alkaline $\mathrm{pH}$. By exposing mucosal homogenates to $\mathrm{pH} 8.0$ pepsinogen remains stable but inactive and will regain full activity when reexposed to $\mathrm{pH} 2 \cdot 0$, the $\mathrm{pH}$ conventionally used in pepsin assays in vitro.

The relation between total gastric pepsinogen secretion in vitro and the peptic activity in vivo is not fully understood. An effort to correlate mucosal pepsinogen accumulation with total peptic activity and peptic cell mass shows good correlation between these parameters in normal and inflamed gastric mucosa. ${ }^{14}$ In this study, patients with superficial gastritis showed significant reduced pepsinogen content and secretion in the presence of a reduced chief cell mass. No clinical data regarding the aetiology of superficial gastritis in these patients are given.

The fact that $H$ pylori infected gastric mucosa has normal pepsinogen activity indicates adequate zymogen production and storage. Pepsinogen synthesis has been found closely linked to secretion and depletion of stores by a well regulated feedback mechanism under in vitro conditions. ${ }^{15}$ The decreased activated pepsinogen activity is possibly the result of local inactivation of secreted pepsin by bacteria or their metabolites or alternately, backflow into the circulation through an epithelium with altered permeability. Supporting this concept is the fact that serum pepsinogen I activity has consequentially found to be raised in both adults $^{1112}$ and children ${ }^{16}{ }^{17}$ with $H$ pylori associated antral gastritis and these concentrations return to normal in most patients after successful therapy. ${ }^{16}$ An alternative possibility for reduced total peptic activity and activated pepsinogen in the antral musoca of $H$ pylori gastritis may be the utilisation of these proteins as energy substrate by the bacteria colonising the stomach. ${ }^{18}$

The mechanism by which $H$ pylori causes reduced peptic activity is unknown. The organism induces decreased acid secretion, at least in the early phase of the disease ${ }^{11}{ }^{17} 19$ but this may persist for weeks or even months. Suppression of acid secretion seems to be directly associated with the presence of the organism overlying the gastric mucosa and to be reversed by antibiotic therapy in the course of the disease. Similarly, our data confirm the direct relationship between active disease and decreased peptic activity as well as normalisation of the activity after antibiotic therapy and eradication of the infection. ${ }^{16}$

The efficacy of metronidazole and amoxicillin has recently been assessed in a group of 32 children with non-specific abdominal pain and $H$ pylori gastritis. Thirty of $32(94 \%)$ children were cleared of $H$ pylori after a six week treatment and nine of $12(75 \%)$ of these still remained free of $H$ pylori after six months. ${ }^{16}$ These results support the $100 \%$ eradication in the 13 patients reinvestigated in this study. Glupczynski and Burette in their recent review article also suggest 
that combination therapy of a bismuth salt and an antibiotic, or two different antibiotics alone, will improve the eradication rate of $H$ pylori and reduce the risk of resistance development. ${ }^{20}$

Experimental inhibition of ${ }^{14} \mathrm{C}$ aminopyrine accumulation of rabbit parietal cells in vitro by whole organisms or sonicated bacteria isolated from patients with $H$ pylori infection suggest the existence of an inhibitory protein. ${ }^{21}$ The protein was further shown to inhibit cAMP release of gastric fundic biopsies and to prevent its stimulation by histamine. ${ }^{22}$ In this regard the adrenergic stimulated pepsinogen secretion mediated by cAMP, ${ }^{23}$ may become an alternate pathway of bacteria induced decrease of peptic activity.

Reduced peptic activity in consonance with achlorhydria may favour opportunistic infection located in or in transit through the upper gastrointestinal tract of these patients. The relationship between these alterations, hypergastrinaemia and chronic ulcer disease has also been suggested. ${ }^{24}$

1 Cadranel S, Goossens H, De Boeck M, Malengereav A Rodesch P, Butzler JP. Campylobacter pyloridis in children. Lancet 1986; i: $735-6$.

2 Cziniv SJ, Dahms BB, Jacobs GH, Kaplan B, Rothstein FC Campylobacter-like organism in association with symptomatic gastritis in children. K Pediatr 1986; 109: 80-3

3 Glassman MS, Schwarz SM, Medow MS, Beneck D, Halata $\mathrm{M}$, Berzin S,et al. Campylobacter pylori-related gastrointestinal disease in children. Dig Dis Sci 1989; 34: 1501-4.

4 Kosune T, Hook J, Rantelin HI, Myllyla G. Age dependent increase in Campylobacter pylori antibodies in blood donors. Scand f Gastroenterol 1989; 24: 110-4.

5 Drumm B, Sherman P, Cutz E, Karmali M. Association of Campylobacter pylori on the gastric mucosa with antral gastritis in children. N Engl f Med 1987; 316: 1557-61.

6 Marshall BJ, McGechie DB, Rogers PA, Glancy RY. Pyloric Campylobacter infection and gastrointestinal diseases. Med F A ust 1985; 162: 439-44.
7 Borsch G, Schmidt G, Wegner M, Adamek R, Leverkos F, Reitemeyer $\mathrm{E}$. Campylobacter pylori: prospective analysis of clinical and histological factors associated with colonization of the upper gastrointestinal tract. Eur $\mathcal{F}$ Clin Invest 1988; 18: $133-8$.

8 Anson M, Mirsky AE. The estimation of pepsin with hemoglobin. $\mathcal{F}$ Gen Physiol 1932; 16: 59-63.

9 Lowry OH, Rosebrough NJ, Farr AL, Randall RJ. Protein measurement with the folin phenol reagent. $\mathcal{F}$ Biol Chem 1951; 193: 265-75.

10 Spiro HM, Schwartz RDL. Superficial gastritis a cause of temporary achlorhydria and hyperpepsinemia. N Engl t Med 1958; 259: 682-4.

11 Ramsey EJ, Carey KV, Peterson WL, Jackson JJ, Murphy FK, Read NW, et al. Epidemic gastritis with hypochlorhydria. Gastroenterology 1979; 76: 1449-57.

12 Graham DY, Alpert LC, Smith JL, Yoshimura $\mathrm{HH}$ Iatrogenic Campylobacter pylori infection is a cause of epidemic achlorhydria. Am $\mathcal{F}$ Gastroenterol 1988; 83: 974-80.

13 Samloff IM. Peptic ulcer. The many proteinases of aggression. Gastroenterology 1989; 96: 586-95.

14 Hengels KJ, Heinrich G, Strohmeyer G. Relationship between peptic cell mass, mucosal pepsinogen concentration and pepsinogen secretion in normal gastric mucosa and gastritis. Dig Dis Sci 1986; 34 (suppl 10): A1184.

15 Defize J, Hunt RH. Control of pepsinogen synthesis and secretion in primary monolayer cultures of canine chief cells. Dig Dis Sci 1988; 33: 1583-91.

16 Oderda G, Varia D, Holton J, Ainley C, Altare F, Ansaldi N. Amoxycillin plus tinidazole for Campylobacter pylori gastritis in children: assessment by serum IgG antibody, pepsinogen I and gastrin level. Lancet 1989; i: 690-2.

17 Blaser MJ. Epidemiology and pathophysiology of Campylobacter pylori infection. Rev Infect Dis 1990; 12 (suppl): S99106.

18 Oderda G, Varia D, Holton J, Dowsett JF, Ansaldi N. Serum pepsinogen I and IgG antibody to Campylobacter pylori in non-specific abdominal pain in children. Gut 1989; 30: non-sp.

19 Morris A, Nicholson G. Ingestion of Campylobacter pyloridis causes gastritis and raised fasting gastric $\mathrm{pH}$. Am $\mathcal{J}$ Gastroenterol 1987; 82: 192-9.

20 Glupczynski Y, Burette A. Drug therapy for HP infection: problems and pitfalls. Am $\mathcal{F}$ Gastroenterol 1990; 85: 1545-51.

21 Cave DR, Vargas M. Effect of Campylobacter pylori protein on acid secretion by parietal cells. Lancet 1989; ii: 187-9.

22 Taha AS, Fraser WD, Kelly RW, Gemmel CG, Lee FD Russel RF. Inhibition of gastric mucosal cyclic AMP by Helicobacter pylori protein. Gut 1990; 31: A1180.

23 Koeltz HR, Hersey SY, Sachs G, Chew GS. Cholinergic and beta adrenergic pepsinogen release by isolated rabbit glands. Am F Physiol 1982; 243: G218-25.

24 Goodwin CS. Duodenal ulcer, Campylobacter pylori and the 'leaky roof' concept. Lancet 1988; ii: 1467-9. 